\title{
OPEM
}

www.opem.org

Oriental Pharmacy and Experimental Medicine 2007 7(4), 379-384

DOI 10.3742/OPEM.2007.7.4.379

\section{Bioactivity of two medicinal plant Xylocarpus granatum Koen. (Meliaceae) and Sarcolobus globosus Wall. (Asclepiadaceae) of Sundarbans mangrove forest}

\author{
M Alamgir*, Ma Rob, DC Kundu, JHK Joy and MM Sarder \\ Pharmacy Discipline, Khulna University, Khulna-9208, Bangladesh
}

\begin{abstract}
SUMMARY
Two medicinal plant of Sundarbans mangrove forest has been tested for the evaluation of growth inhibitory and antibacterial activity. The methanol extract of Xylocarpus granatum stem bark showed potent wheat rootlet $\left(\mathrm{IC}_{50}=0.01 \mu \mathrm{g} / \mathrm{ml}\right)$ and shoot $\left(\mathrm{IC}_{50}=0.23 \mu \mathrm{g} / \mathrm{ml}\right)$ growth inhibitory activity in a concentration related manner. The growth inhibitory activity was markedly decreased in residual methanol extract. The methanol extract showed antibacterial activity (MIC $>3 \mathrm{mg} / \mathrm{ml}$ ) against Bacillus subtilis, Staphylococcus aureous and Proteus vulgaris. The residual methanol extract did not show any antibacterial activity. The results suggest the bioactive principle(s) of Xylocarpus granatum may be relatively non polar compound(s). The methanol extract and residual methanol extract of Sarcolobus globosus stem showed poor wheat rootlet and shoot growth inhibitory activity and no antibacterial activity.
\end{abstract}

Key words: Bioactivity; Sundarbans; Mangrove; Wheat rootlet growth inhibition; Antibacterial activity

\section{INTRODUCTION}

The Sundarbans mangrove forest is a globally significant ecosystem rich in plant biodiversity. It has been reported that the Sundarbans provides habitat for around 334 plants (Prain, 1903). In recognition of the global significance of the Sundarbans, UNESCO declared it as a world heritage site in December 1997. The Sundarbans is the largest contiguous block of mangrove forest in the world. Located along the mouth of the Bay of Bengal, it extends over 10,000 square kilometers in Bangladesh and India. Sixty percent of the area belongs to

*Correspondence: M Alamgir, Pharmacy Discipline, Khulna University, Khulna-9208, Bangladesh. (Present address) School of Chemistry, University of New South Wales, Sydney-2052, Australia. E-mail: m19alamgir @yahoo.com
Bangladesh. The forest lies in the northern south of the tropic cancer between $21^{\circ} 30^{\prime}$ and $22^{\circ} 30^{\prime}$ north latitude and $89^{\circ}$ and $90^{\circ}$ east longitudes (Chaudhuri and Naithani, 1985).

World wide there are now a growing interest for searching new drug compounds form plants for the treatment of diseases. The natural world, especially the plant kingdom, is recognized as a valuable source of diverse molecules. The Sundarbans reserved forest has a rich biodiversity of flowering plants and many of these have been used in traditional medicine, although the chemistry and bioactivity of the flora remains comparatively uninvestigated scientifically. These plants may represent a valuable source of novel drug compounds for the characterization and subsequent development of pharmaceutical modalities. We have started a systematic screening of the medicinal plants of 
Sundarbans with the purpose of discovering new bioactive compounds (Alamgir et al., 2006; Rajia et al., 2006).

Xylocarpus granatum is a moderate size tree and Sarcolobus globosus is a large climber that grows in the Sundarbans, the coasts of Indo-China, Malaya, Australia (Prain, 1903; Kirtikar and Basu, 1990). In traditional medicine Xylocarpus granatum bark is used for dysentery, diarrhoea and other abdominal troubles, and as febrifuges. The seed ash mixed with sulfur and coconut oil is applied as ointment for itch. Fruit is used as a cure for swellings of the breast and elephantiasis (Yusuf et al., 1994). We have recently reported the antidiarrhoeal activity of Xylocarpus granatum (Rouf et al., 2006). Limonoids (Alvi et al., 1991; Kokpol et al., 1996; Wu et al., 2003; Wu et al., 2004a; Wu et al., 2004b), lignins, tannins (Shinoda et al., 1984; Shinoda et al., 1985), alkaloids (Chou et al., 1977), and sterols (Majumdar and Patra, 1976) had been isolated from Xylocarpus granatum. Sarcolobus globosus has been used in traditional medicine against rheumatism, dengue and fever (Johnson, 1999). Seeds showed cardiotonic action (Jabbar and Khan, 1982). Glycosidic extract exhibited neuromuscular blocking activity (Mustafa et al., 1990) and smooth muscle inhibitory activity (Mustafa, 1993). Our research collaborator in recent times reported the 15-lipooxygease inhibitory and radical scavenging activity (Wangensteen et al., 2006) and isolated new rotenoids and isoflavonoids from Sarcolobus globosus (Wangensteen et al., 2005). The present study was performed as a preliminary study to investigate the effect of Xylocarpus granatum and Sarcolobus globosus on wheat rootlet and shoot growth inhibition bioassay and in vitro antimicrobial activity.

\section{MATERIALS AND METHODS}

\section{Plant materials}

Xylocarpus granatum Koen. syn. Carapa obovata Blume (Fam: Meliaceae) stem bark and Sarcolobus globosus Wall. (Asclepiadaceae) stems were collected from the Burigoalini Range of the Sundarbans forest, Khulna, Bangladesh, in October 2001 and identified from the Bangladesh National Herbarium (Xylocarpus granatum, DACB no. 12791; Sarcolobus globosus, DACB no. 16609) Mirpur, Dhaka. The plants were air and oven $\left(40^{\circ}\right.$ to $\left.45^{\circ} \mathrm{C}\right)$ dried and was grinded by hammer mill to a fine powder.

\section{The extract}

The plant was extracted by cold extraction method. The dried powder was soaked in $80 \%$ of methanol in a glass container for seven days. The extract was separated from the plant debris by filtration and was concentrated by evaporation using rotary vacuum evaporator. They were dried under vacuum to give Xylocarpus granatum (172.8 g; yield $43.2 \%$ ) and Sarcolobus globosus (144.2 g; yield 36.05\%). The methanol extract was further partitioned using nhexane and chloroform which gave the residual methanol fraction. The methanol extract (ME) and residual methanol fraction (RMF) were subjected to the following bioactivity studies.

\section{Wheat rootlet and shoot growth inhibition bioassay} Ten germinated wheat grains (Triticum awstivum L., cv Buck Nandti) selected at random, were placed on a filter paper in a Petri dish containing $5 \mathrm{ml}$ of the methanol extract and residual methanol fraction solutions of different concentrations (250, $500,1,000$ and $1,500 \mu \mathrm{g} / \mathrm{ml})$. The Petri dishes were incubated for 5 days under the normal conditions in a dark place. The longest rootlet length and shoot length of each seed was measured and the inhibition was calculated as a percentage relative to the length of the rootlets and shoots in the controls with tap water. The average rootlet and shoot length of the ten seeds for each concentration was used in the percentage of growth inhibition calculation. The $\mathrm{IC}_{50}$ values were calculated from the straight line drawn from different log concentration vs. percentage inhibition graph (Mongelli et al., 1995).

\section{Antibacterial activity test}

The antibacterial activity test was done at Gono 
Shasthaya Vaccine Research and Diagnostic Laboratory, Savar, Dhaka using the standard agar dilution method. The sterile Mueller-Hinton agar media was poured into a sterile Petri dish in aseptic condition at room temperature. The medium was incubated at $37^{\circ} \mathrm{C}$ for $48 \mathrm{~h}$ before use to check whether there was any infection in the medium. Culture of the test organism was streaked uniformly over the medium using an inoculating loop in aseptic condition. Concentrations of the extracts used in the test were $1 \mathrm{mg} / \mathrm{ml}, 2 \mathrm{mg} / \mathrm{ml}$ and 3 $\mathrm{mg} / \mathrm{ml}$ and they were incubated in an incubator (Gallenkamp, Germany) at $37^{\circ} \mathrm{C}$ for $24 \mathrm{~h}$ for culture sensitivity test (Colee, 1967). The microorganisms used in this study were clinical bacterial isolates collected from Gono Shasthaya Hospital, Savar, Dhaka. The microorganisms used were Escherichia coli, Staphylococcus aureous, Pseudomonas aeruginosa, Proteus vulgaris and Bacillus subtilis.

\section{Phytochemical screening}

The phytochemical tests for carbohydrates, alkaloids, saponins, glycosides, tannins, flavonoids were performed according to Ghani (1998).

\section{RESULTS}

Wheat rootlet and shoot growth inhibition bioassay From the wheat rootlet and shoot (Table 1) growth inhibition bioassay we observed that the methanol extract of Xylocarpus granatum had potent dose dependent growth inhibitory effect on both the wheat rootlet and shoot. The $\mathrm{IC}_{50}$ value of the methanol extract was observed $0.01 \mu \mathrm{g} / \mathrm{ml}$ for rootlet and $0.23 \mu \mathrm{g} / \mathrm{ml}$ for shoot. The residual methanol extract of Xylocarpus granatum also had a high growth inhibitory effect on both the wheat rootlet and shoot. The inhibition of both the rootlet and shoot was concentration dependent. The $\mathrm{IC}_{50}$ value of the residual methanol extract was $705.16 \mu \mathrm{g} / \mathrm{ml}$ for rootlet and $1403.16 \mu \mathrm{g} / \mathrm{ml}$ for shoot.

The wheat rootlet and shoot (Table 1) growth inhibition bioassay revealed that the methanol extract of Sarcolobus globosus had a dose dependent growth inhibitory effect on both the wheat rootlet and shoot. The $\mathrm{IC}_{50}$ value of the methanol extract was 364.88 $\mu \mathrm{g} / \mathrm{ml}$ for rootlet and $851.86 \mu \mathrm{g} / \mathrm{ml}$ for shoot. The $\mathrm{IC}_{50}$ of the residual methanol extract was found $557.85 \mu \mathrm{g} / \mathrm{ml}$ for rootlet and $665.49 \mu \mathrm{g} / \mathrm{ml}$ for shoot.

\section{Antibacterial activity test}

The antimicrobial study (Table 2) of Xylocarpus granatum showed that the methanol extract (ME) had antibacterial activity at the $3 \mathrm{mg} / \mathrm{ml}$ concentration level against gram positive bacteria $S$. aureus and $B$. subtilis and gram negative bacteria $P$. vulgaris. The extract was found inactive against $E$. coli and $P$. aeruginosa. The residual methanol extract (RME) was found inactive against the entire tested microorganism. The Sarcolobus globosus showed that both the methanol extract and residual methanol extract did not show any antibacterial activity against the gram positive bacteria and gram negative bacteria in our experiment.

Table 1. Wheat rootlet and shoot growth inhibitory activity of Xylocarpus granatum and Sarcolobus globosus

\begin{tabular}{|c|c|c|c|c|}
\hline \multirow{2}{*}{ Experiment } & \multicolumn{2}{|c|}{ Xylocarpus granatum } & \multicolumn{2}{|c|}{ Sarcolobus globosus } \\
\hline & $\mathrm{IC}_{50}(\mu \mathrm{g} / \mathrm{ml})$ & Regression equation & $\mathrm{IC}_{50}(\mu \mathrm{g} / \mathrm{ml})$ & Regression equation \\
\hline \multicolumn{5}{|c|}{ Methanol extract } \\
\hline Rootlet & 0.01 & $Y=9.87 X+70.03$ & 364.88 & $Y=49.13 X-75.88$ \\
\hline Shoot & 0.23 & $Y=13.36 X+8.47$ & 851.86 & $Y=88.33 X-208.84$ \\
\hline \multicolumn{5}{|c|}{ Residual methanol extract } \\
\hline Rootlet & 705.16 & $Y=81.65 X-182.58$ & 557.85 & $Y=134.41 X-319.16$ \\
\hline Shoot & 1403.16 & $Y=39.67 X-74.87$ & 665.49 & $Y=117.10 X-280.59$ \\
\hline
\end{tabular}

$\mathrm{IC}_{50}$ : Inhibitory concentration $50 \%$ of length $(\mu \mathrm{g} / \mathrm{ml})$ 
Table 2. Antibacterial activity of Xylocarpus granatum and Sarcolobus globosus (MIC, g/ml)

\begin{tabular}{llccc}
\hline \multirow{2}{*}{ Microorganisms } & \multicolumn{2}{c}{ Xylocarpus granatum } & \multicolumn{2}{c}{ Sarcolobus globosus } \\
\cline { 2 - 4 } & ME & RME & ME & RME \\
\hline Gram positive bacteria & 3 & - & - & - \\
Bacillus subtilis & 3 & - & - & - \\
Staphylococcus aureus & & & - \\
Gram negative bacteria & - & - & - \\
Escherichia coli & 3 & - & - \\
Proteus vulgaris & - & - & - \\
Pseudomonas aeruginosa & & & - \\
\hline
\end{tabular}

- : Not active; ME: Methanol extract; RME: Residual methanol extract

\section{Phytochemical screening}

The phytochemical study of the Xylocarpus granatum showed the presence of carbohydrate, saponins, tannins and flavonoids and absence of alkaloids and glycosides. The Sarcolobus globosus showed the presence of carbohydrate, saponins, tannins, glycosides and flavonoids and absence of alkaloids.

\section{DISCUSSION}

During the rapid growth of the root and shoot from seeds the cells are divides by mitosis. We have performed the wheat rootlet and shoot growth inhibition bioassay to observe the effect of the methanol extract and residual methanol extract on the mitotic cell division of the rootlet and shoot of wheat grain. Wheat rootlet growth inhibition bioassay has been previously reported as a monitor for detecting biological activities (Puyvelde et al., 1988; Gonzalez et al., 1993; Mongelli et al., 1995). Root and shoot growth in plants also involves the action of specific growth factors and hormones, and thus the mechanism of action of the extract on growth inhibition may not necessarily reflect a direct inhibition of mitosis alone

The ethanol extract and residual methanol extract of Xylocarpus granatum (Meliaceae) showed a potent growth inhibitory effect on both the wheat rootlet and shoot growth inhibition bioassay in a dose dependent manner. Whereas the residual methanol extract exhibited less inhibitory effect than the methanol extract. However, both the extracts indicated a more pronounced inhibitory effect on the rootlet growth than the shoot growth. Removal of the non polar compounds (by n-hexane and chloroform) from the methanol extract reduced the inhibitory activity both on the rootlet and shoot growth, suggests the growth inhibitory active principle(s) may be relatively non polar. Meliaceae contains a variety of compounds types but specially pentacyclic triterpenoids, limonoids. A considerable number of quite different functions have been ascribed to plants terpenoids. Their growth regulating properties are very well documented, two of the major classes of growth regulators are the sesquiterpenoid abscisins and the diterpenoid gibberellins (Harborne, 1973). We can assume that the limonoids isolated previously from Xylocarpus granatum (Alvi et al., 1991; Kokpol et al., 1996) may cause this wheat rootlet and shoot growth inhibitory effect by interfering with the mitotic cell division.

The methanol extract and residual methanol extract of Sarcolobus globosus showed a poor growth inhibitory effect on the wheat rootlet and shoot growth inhibition bioassay (Table 1). The methanol extract displayed a higher inhibitory effect than the residual methanol extract on wheat rootlet growth. Removal of the non polar compounds (by nhexane and chloroform) from the methanol extract increased the inhibitory activity on the shoot growth, but decreased activity on the rootlet growth compared to residual methanol extract. In 
this short study it is not possible to mention which type of compound is responsible for this activity, but we can assume saponins or flavonoids present in the extracts may cause this inhibition.

In particular, the search for components with antimicrobial activity has gained increasing importance in recent times, due to growing worldwide concern about the alarming increase in the rate of infection by antibiotic-resistant microorganisms (Davies, 1994). Remarkable diversity of chemicals present in biological samples has tremendous potential in search of new antimicrobial agents (Rahman et al., 2001). The methanol extract of Xylocarpus granatum showed antibacterial activity, but residual methanol extract was found inactive against the tested microorganisms. Fractionation of the methanol extract (by n-hexane and chloroform) removes the antibacterial activity, suggests that the active antibacterial principle(s) may be relatively non polar compound(s). It is also known that triterpenes have a protective function in repelling insect and microbial attack (Harborne, 1973). Thus the triterpenes may be involved in the antimicrobial activity of Xylocarpus granatum. Whereas, Sarcolobus globosus did not show any antibacterial activity against the microorganisms tested in our experiment. Resistance of the clinical bacterial isolates could be the cause of this ineffectiveness.

The antibacterial activity of Xylocarpus granatum provides some basis of the treatment for diarrhea in traditional medicine. In addition, Xylocarpus granatum possess potential to be a source of cytotoxic molecule(s) than Sarcolobus globosus. The mechanism underlying for these two activity might be for single compound or synergistic effect of multiple compounds in the extracts Further studies are required to explore the activity on different models and to isolate the active component(s) responsible for this antibacterial and growth inhibition activity.

\section{REFERENCES}

Alamgir M, Alam SMS, Alaul M, Rashid M, Hasan M,
Choudhuri MSK. (2006) Preliminary evaluation of some medicinal plants of Sundarbans mangrove forest on central nervous system. Orient. Pharm. Exp. Med. 6, 215-220.

Alvi KA, Crews P, Aalbersberg B, Prasad R. (1991) Limonoids from the Fijian medicinal plant dabi (Xylocarpus). Tetrahedron 47, 8943-8948.

Chaudhuri AB, Naithani HB. (1985) A Comprehensive Survey of Tropical Mangrove Forests of Sunderbans and Andamans, Part 1. International Book Distribution, Dehra Dun, India.

Chou FY, Hostettmann K, Kubo I, Nakanishi K, Taniguchi M. (1977) Isolation of an insect antifeedant $\mathrm{N}$-methylflindersine and several benz[c] phenanthridine alkaloids from East African plants; a comment on chelerythrine. Heterocycles 7, 969-977.

Colee JD. (1967) Applied Medical Microbiology. p. 93, Science Pub., London.

Davies J. (1994) Inactivation of antibiotics and the dissemination of resistance genes. Science 264, 375-382.

Ghani A. (1998) Medicinal Plants of Bangladesh-chemical constituents and uses. 1st ed, p.336, Asiatic Society of Bangladesh, Dhaka.

Gonzalez A, Ferreira F, Vazquez A, Moyna P, Alonso PE. (1993) Biological screening of Uruguayan medicinal plants. J. Ethnopharmacol. 39, 17-20.

Harborne JB. (1973) Phytochemical Methods. A Guide to Modern Techniques of Plant Analysis. p.110, Chapman and Hall, London.

Jabbar A, Khan MR. (1982) Pharmacological studies on the glycosides from Sarcolobus globosus. J. Bangladesh Academy Sci. 6, 171-173.

Johnson T. (1999) CRC Ethnobotany Desk Reference. p. 747, CRC Press, Boca Raton, Florida.

Kirtikar KR, Basu BD. (1984) Indian Medicinal Plants. 2 nd ed., Vol.III; Bishen Sigh Mahendra Pal Singh, Dehra Dun, India.

Kokpol U, Chavasiri W, Tip-pyang S, Veerachato G, Zhao F, Simpson J, Weavers RT. (1996) A limonoid from Xylocarpus granatum. Phytochemistry 41, 903-905.

Majumdar SG, Patra G. (1976). Chemical investigation of some mangrove species. Part II. Carapa obovata Bl. J. Indian Chem. Soc. 53, 947-948.

Mongelli E, Desmarchelier C, Giulietti A, Coussio J, Ciccia G. (1995) Bioactivity of certain medicinal latexes used by the Ese'ejas. J. Ethnopharmacol. 47, 159-163. 
Mustafa MR. (1993) Inhibition of calcium-dependent contractions of the isolated guinea-pig ileal longitudinal muscle and taenia coli by the total glycosidic extract of the plant Sarcolobus globosus. Toxicon 31, 67-74.

Mustafa MR, Hadi A, Hamid A. (1990) Neuromuscular blocking activity of a glycosidic extract of the plant Sarcolobus globosus. Toxicon 28, 1237-1239.

Prain D. (1903) Flora of the Sundribuns. pp. 231-390, Record of the Botanical Survey of India, Superintendent of Government Printing, Calcutta.

Puyvelde VL, Kimpe ND, Ayobaringa F, Costa J, Nshimyukiza P, Boily Y, Hakizamungu E, Schamp N. (1988) Wheat rootlet growth inhibition test of Rwandese medicinal plants: Active principles of Tetradenia riparia and Diplolophium africanum. J. Ethnopharmacol. 24, 233-246.

Rahman A, Choudhary I, Thomson WJ. (2001) Bioassay Techniques for Drug Development. p.14, Harwood Academic Publishers, The Netherlands.

Rouf R, Uddin SJ, Shilpi JA, Alamgir M. (2006) Assessment of antidiarrhoeal activity of the methanol extract of Xylocarpus granatum bark in mice model. J. Ethnopharmacol. (published online) in press doi: 10.1016/j.jep.2006.08.015.

Shinoda Y, Ogisu M, Inaba M, Tajima T. (1984) Chemical composition of mangroves I. Gifu Daigaku Nogakubu Kenkyu Hokoku 49, 119-125.
Shinoda Y, Ogisu M, Iwata S, Tajima T. (1985) Chemical composition of mangroves II. Gifu Daigaku Nogakubu Kenkyu Hokoku 50, 155-165.

Siddiqi NA. (2001) Mangrove Forestry in Bangladesh. Institute of Forestry and Environmental Sciences, University of Chittagong, Bangladesh.

Wangensteen H, Miron A, Alamgir M, Rajia S, Samuelsen AB, Malterud KE. (2006) Antioxidant and 15-lipoxygenase inhibitory activity of rotenoids, isoflavones, and phenolic glycosides from Sarcolobus globosus. Fitoterapia 77, 290-295.

Wangensteen H, Alamgir M, Rajia S, Samuelsen AB, Malterud KE. (2005) Rotenoids and isoflavones from Sarcolobus globosus. Planta Med. 71, 754-758.

Wu J, Xiao Q, Huang J, Xiao Z, Qi S, Li Q, Zhang S. (2004a) Xyloccensins $O$ and $P$, Unique 8,9,30Phragmalin Ortho Esters from Xylocarpus granatum. Org. Lett. 6, 1841-1844.

Wu J, Zhang S, Xiao Q, Li Q, Huang J, Long L, Huang L. (2004b) Xyloccensin L, a novel limonoid from Xylocarpus granatum. Tetrahedron Lett. 45, 591-593.

Wu J, Zhang S, Xiao Q, Li Q, Huang J, Xiao Z, Long L. (2003) Xyloccensin M and N, two new B,D-seco limonoids from Xylocarpus granatum. Zeitschrift fuer Naturforschung, B: Chemical Sciences 58, 1216-1219.

Yusuf M, Chowdhury JU, Wahab MA, Begum J. (1994) Medicinal Plants of Bangladesh. BCSIR Laboratories, Chittagong, Bangladesh, p. 263. 